\title{
Studies on Cyclopolymerization in the Presence of Alkylaluminum Chlorides VII. Cyclopolymerizations of Acrylates and Methacrylates Containing Oligooxyethylene Units in the 11-20-Membered-Ring Region
}

\author{
Kazuaki YoKotA, Toyoji KAKUCHI, Takashi IIYAMA, \\ and Yoshiyuki TAKADA \\ Department of Chemical Process Engineering, Faculty of Engineering, \\ Hokkaido University, Sapporo 060, Japan
}

(Received October 3, 1983)

\begin{abstract}
An investigation of cyclopolymerization in the presence of alkylaluminum chlorides was extented to 2-[2-(o-allylphenoxy)ethoxy]ethyl acrylate and methacrylate, and higher homologues containing oligooxyethylene units capable of forming 14-, 17- and 20-membered rings, respectively. Although the effect of alkylaluminum chlorides was gradually reduced with increasing ring size, it was remarkable in the formation of 14-membered rings for methacrylates and even the 20 -membered rings for acrylates. When combined with previous results for the analogues containing oligomethylene units, the present data showed that oxyethylene groups had favorable effects on cyclopolymerization. A plot of the extent of cyclization against ring size showed that monomers containing oligooxyethylene units had a greater cyclization tendency than those containing oligomethylene units. The relation of $\log \left(k_{\mathrm{p}} / k_{\mathrm{c}}\right)$ against ring size gave a straight line in the ring-size range from 11 to 20 for acrylates.
\end{abstract}

KEY WORDS Cyclopolymerization / Alkylaluminum Chlorides / Nonconjugated Diene / Acrylates / Methacrylates / Oligooxyethylene Units / Radical Polymerization / Large-Size Ring / Oxygen Atom Effect / Cyclization /

The cyclopolymerization of nonconjugated dienes such as $o$-allylphenyl acrylate (APA) containing electropositive and electronegative double bonds greatly increased through treatment with alkylaluminum chlorides. ${ }^{1,2}$ The influence of ring size on cyclopolymerization for monomers $\mathbf{1}$ and $\mathbf{2}$ in the 11-19membered-ring region has already been reported. $^{3}$ The effects of alkylaluminum chlorides was remarkable in the formation of rings up to 13 members for acrylates and up to 11 members for methacrylates, but dropped off for higher homologues. Oxygen atom effects arising from the replacement of a methylene group with an oxygen atom on the formation of aromatic ethers via intramolecular Williamson synthesis were generally found to facilitate ring closure by Illuminati et al., Therefore, the introduction of oxygen atoms to a methylene chain should cause a cyclization reaction to occur more readily in cyclopolymerization. A relative evaluation of oxygen atom effects on cyclopolymerization may be possible on the basis of a comparison of the experimental data on monomers 3 and $\mathbf{4}$ (eq 1), with that of monomers $\mathbf{1}$ and 2 . We have already reported on the polymerizations of $\mathrm{A}(\mathrm{OE}) \mathrm{A}-11^{2}$ and $\mathrm{A}(\mathrm{OE}) \mathrm{M}-11 .^{3}$ In this report, our study has been extended to the cyclopolymerization of higher homologues in $\mathbf{3}$ and $\mathbf{4}$. The terms oligomethylene and oligooxyethylene are used as designations for monomers $\mathbf{1}$ and $\mathbf{2}$, and $\mathbf{3}$ and $\mathbf{4}$. 
K. YoKota et al.

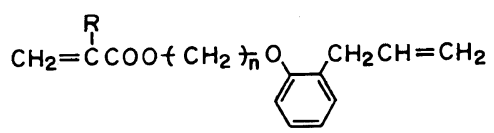

1. $\mathrm{R}=\mathrm{H}$ (acrylates): $n=2, \mathrm{~A}(\mathrm{OE}) \mathrm{A}-11$ (ring size); $n=4$, $\mathrm{A}(\mathrm{OB}) \mathrm{A}-13 ; n=6, \mathrm{~A}(\mathrm{OH}) \mathrm{A}-15 ; n=10, \mathrm{~A}(\mathrm{OD}) \mathrm{A}-19$.

2. $\mathrm{R}=\mathrm{CH}_{3}$ (methacrylates): $n=2, \mathrm{~A}(\mathrm{OE}) \mathrm{M}-11 ; n=4, \mathrm{~A}(\mathrm{OB}) \mathrm{M}-13$; $n=6, \mathrm{~A}(\mathrm{OH}) \mathrm{M}-15 ; n=10, \mathrm{~A}(\mathrm{OD}) \mathrm{M}-19$.

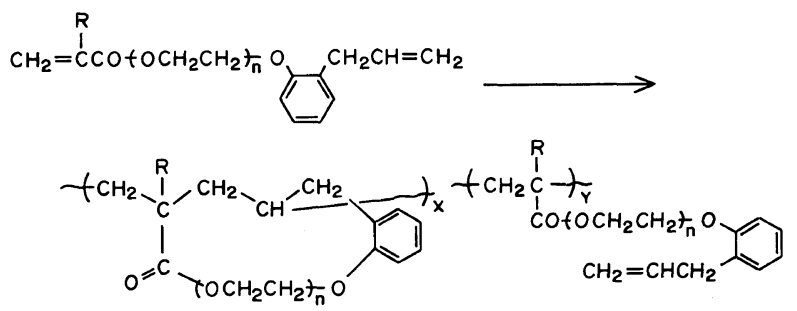

3. $\mathrm{R}=\mathrm{H}$ (acrylates): $n=1, \mathrm{~A}(\mathrm{OE}) \mathrm{A}-11$ (ring size); $n=2$, $\mathrm{A}(\mathrm{OE})_{2} \mathrm{~A}-14 ; n=3, \mathrm{~A}(\mathrm{OE})_{3} \mathrm{~A}-17 ; n=4, \mathrm{~A}(\mathrm{OE})_{4} \mathrm{~A}-20$.

4. $\mathrm{R}=\mathrm{CH}_{3}$ (methacrylates): $n=1, \mathrm{~A}(\mathrm{OE}) \mathrm{M}-11 ; n=2, \mathrm{~A}(\mathrm{OE})_{2} \mathrm{M}-14$; $n=3, \mathrm{~A}(\mathrm{OE})_{3} \mathrm{M}-17 ; n=4, \mathrm{~A}(\mathrm{OE})_{4} \mathrm{M}-20$.

\section{EXPERIMENTAL}

\section{Monomers}

Monomers 3 and 4 were obtained by a reaction of the corresponding alcohols with acryloyl or methacryloyl chloride, following a procedure similar to that described in the previous papers. ${ }^{1,2}$

2-[2-(o-Allylphenoxy)ethoxy]ethyl acrylate $\left(\mathrm{A}(\mathrm{OE})_{2} \mathrm{~A}-14\right)$ : bp $159-161^{\circ} \mathrm{C}$ (2 torr); NMR $\left(\mathrm{CCl}_{4}\right) \delta 3.30\left(\mathrm{~d}, 2,-\mathrm{CH}_{2} \mathrm{CH}=\right), 3.65$ and 3.71 $\left(\mathrm{t} \times 2,4,-\mathrm{CH}_{2} \mathrm{OCH}_{2}-\right), 4.01\left(\mathrm{t}, 2, \mathrm{ArOCH}_{2}-\right)$, $4.19\left(\mathrm{t}, 2,-\mathrm{COOCH}_{2}-\right), 4.90$ (d, 1, cis$\left.\mathrm{CH}_{2}=\mathrm{CH}-\right), 4.93$ (d, 1, trans $\left.-\mathrm{C}_{2}=\mathrm{CH}-\right)$, $5.60-6.40(\mathrm{~m}, 4$, vinyl $\mathrm{H}), 6.70(\mathrm{t} \times 2,2$, 4- and 5-ArH), 6.95 (d, 2, 3- and 6-ArH).

Anal. Calcd for $\mathrm{C}_{16} \mathrm{H}_{20} \mathrm{O}_{4}: \mathrm{C}, 69.54 \% ; \mathrm{H}$, $7.30 \%$. Found: C, $69.13 \%, \mathrm{H}, 7.42 \%$.

2-[2-(o-Allylphenoxy)diethoxy]ethyl acrylate $\left(\mathrm{A}(\mathrm{OE})_{3} \mathrm{~A}-17\right)$ : bp $142-143^{\circ} \mathrm{C}\left(2 \times 10^{-5}\right.$ torr); NMR $\left(\mathrm{CCl}_{4}\right) \delta 3.30(\mathrm{~d}, 2), 3.47-3.80$ $(\mathrm{m}, 8), 4.03(\mathrm{t}, 2), 4.18(\mathrm{t}, 2), 4.92(\mathrm{~d}, 1), 4.94(\mathrm{~d}$, 1), $5.60-6.41(\mathrm{~m}, 4), 6.71(\mathrm{t} \times 2,2), 6.96(\mathrm{~d}, 2)$.

Anal. Calcd for $\mathrm{C}_{18} \mathrm{H}_{24} \mathrm{O}_{5}: \mathrm{C}, 67.48 \% ; \mathrm{H}$, $7.55 \%$. Found: C, $67.03 \%$; $\mathrm{H}, 7.62 \%$.

2-[2-(o-Allylphenoxy)triethoxy]ethyl acrylate $\left(\mathrm{A}\left(\mathrm{OE}_{4} \mathrm{~A}-20\right)\right.$ : bp $159-163^{\circ} \mathrm{C}\left(2 \times 10^{-5}\right.$ torr); NMR $\left(\mathrm{CCl}_{4}\right) \delta 3.31(\mathrm{~d}, 2), 3.52-3.79$ $(\mathrm{m}, 12), 4.04(\mathrm{t}, 2), 4.18(\mathrm{t}, 2), 4.93(\mathrm{~d}, 1), 4.96$ $(\mathrm{d}, 1), 5.62-6.44(\mathrm{~m}, 4), 6.73(\mathrm{t} \times 2,2), 6.98$ (d, 2).

Anal. Calcd for $\mathrm{C}_{20} \mathrm{H}_{28} \mathrm{O}_{6}: \mathrm{C}, 65.91 \% ; \mathrm{H}$, $7.74 \%$. Found: C, $65.90 \%$; H, 7.72\%.

2-[2-(o-Allylphenoxy)ethoxy]ethyl methacrylate $\left(\mathrm{A}(\mathrm{OE})_{2} \mathrm{M}-14\right)$ : bp $155-159^{\circ} \mathrm{C}$ (2 torr); NMR $\left(\mathrm{CCl}_{4}\right) \delta 1.89\left(\mathrm{~s}, 3,-\mathrm{C}\left(\mathrm{CH}_{3}\right)=\right), 3.30$ (d, 2, $\left.-\mathrm{C}_{2} \mathrm{CH}=\right), \quad 3.58-3.78 \quad(\mathrm{~m}, \quad 4$, $\left.-\mathrm{C}_{2} \mathrm{OC}_{2}-\right), 4.02\left(\mathrm{t}, 2, \mathrm{ArOCH}_{2}-\right), 4.16(\mathrm{t}, 2$, $-\mathrm{COOCH}_{2}-$ ), 4.88 (d, 1, cis $-\mathrm{CH}_{2}=\mathrm{CH}-$ ), 4.91 (d, 1, trans $-\mathrm{CH}_{2}=\mathrm{CH}-$ ), 5.40 (s, 1, cis- $\underline{\mathrm{H}}_{2}=$ $\left.\mathrm{C}\left(\mathrm{CH}_{3}\right)^{-}\right), 5.95$ (s, 1, trans $\left.-\mathrm{CH}_{2}=\mathrm{C}\left(\mathrm{CH}_{3}\right)^{-}\right)$, $5.61-6.03\left(\mathrm{~m}, 1, \mathrm{CH}_{2}=\mathrm{C} \underline{\mathrm{H}}-\right), 6.67(\mathrm{t} \times 2,2,4-$ and 5-ArH), 6.92 (d, 2, 3- and 6-ArH).

Anal. Calcd for $\mathrm{C}_{17} \mathrm{H}_{22} \mathrm{O}_{4}: \mathrm{C}, 70.32 \% ; \mathrm{H}$, $7.64 \%$. Found C, 70.24\%; H, 7.65\%.

2-[2-(o-Allylphenoxy)diethoxy]ethyl methacrylate $\left(\mathrm{A}(\mathrm{OE})_{3} \mathrm{M}-17\right)$ : bp $143-145^{\circ} \mathrm{C}(1 \times$ $10^{-4}$ torr); NMR $\left(\mathrm{CCl}_{4}\right) \delta 1.88(\mathrm{~s}, 3), 3.31$ (d, 2), 3.56-3.78 (m, 8), $4.02(\mathrm{t}, 2), 4.17(\mathrm{t}, 2)$, $4.92(\mathrm{~d}, 1), 4.94(\mathrm{~d}, 1), 5.42(\mathrm{~s}, 1), 6.00(\mathrm{~s}, 1)$, 5.65-6.09 (m, 1), $6.71(\mathrm{t} \times 2,2), 6.93(\mathrm{~d}, 2)$. Anal. Calcd for $\mathrm{C}_{19} \mathrm{H}_{26} \mathrm{O}_{5}: \mathrm{C}, 68.24 \% ; \mathrm{H}$, $7.84 \%$. Found: C, $68.20 \%$; H, 7.87\%.

2-[2-(o-Allylphenoxy)triethoxy]ethyl meth- 
acrylate $\left(\mathrm{A}(\mathrm{OE})_{4} \mathrm{M}-20\right)$ : bp $162-163^{\circ} \mathrm{C}(5 \times$ $10^{-5}$ torr), NMR $\left(\mathrm{CCl}_{4}\right) \delta 1.88(\mathrm{~s}, 3), 3.25$ (d, 2), 3.47-3.77 (m, 12), $4.01(\mathrm{t}, 2), 4.12(\mathrm{t}, 2)$, $4.87(\mathrm{~d}, 1), 4.88(\mathrm{~d}, 1), 5.37(\mathrm{~s}, 1), 5.92(\mathrm{~s}, 1)$, 5.58-6.02 (m, 1), $6.63(\mathrm{t} \times 2,2), 6.88(\mathrm{~d}, 2)$.

Anal. Calcd for $\mathrm{C}_{21} \mathrm{H}_{30} \mathrm{O}_{6}: \mathrm{C}, 66.64 \% ; \mathrm{H}$, $7.99 \%$. Found: C, $66.39 \%$; H, $8.10 \%$.

\section{Polymerization}

The polymerizations were carried out as described in a previous paper. ${ }^{1}$

\section{Analysis}

The extent of cyclization in polymers was determined by the procedure described in the previous papers. ${ }^{1,2}$

\section{RESULTS AND DISCUSSION}

Experimental results on conventional radical polymerization without alkylaluminum chlorides are presented in Table I. The products obtained were somewhat sticky semisolids and soluble in benzene and chloroform. The IR spectrum of the polymer was indicative of a large amount of residual double bonds in the form of pendant allylic double bonds, since the characteristic absorptions due to acrylic and methacrylic double bonds had disappeared. In spite of the rate of the polymerization, the extent of cyclization was much higher for acrylates than for methacrylates.

Polymerizations in the presence of alkylalu- minum chlorides were carried out at a monomer concentration of $0.5 \mathrm{~mol} \mathrm{dm}^{-3}$ at $40^{\circ} \mathrm{C}$. The reaction systems were homogeneous except that a precipitate was obtained in the case of $\mathrm{A}(\mathrm{OE})_{2} \mathrm{~A}$ with $\mathrm{AlEtCl}{ }_{2}$. The polymers were colorless powders for $\mathrm{A}(\mathrm{OE})_{2} \mathrm{~A}$ and $\mathrm{A}(\mathrm{OE})_{2} \mathrm{M}$, colorless powders or semi-solids for $\mathrm{A}(\mathrm{OE})_{3} \mathrm{~A}$ and $\mathrm{A}(\mathrm{OE})_{3} \mathrm{M}$, and somewhat sticky semisolids for $\mathrm{A}(\mathrm{OE})_{4} \mathrm{~A}$ and $\mathrm{A}(\mathrm{OE})_{4} \mathrm{M}$. Some of polymers obtained from $\mathrm{A}(\mathrm{OE})_{2} \mathrm{~A}$ and $\mathrm{A}(\mathrm{OE})_{3} \mathrm{~A}$ was insoluble in chloroform. The IR spectrum of such polymers showed that the residual double bonds were allylic. The effects

Table I. Radical polymerization of 2-[2-(oallylphenoxy)ethoxy]ethyl, 2-[2-(oallylphenoxy)diethoxy]ethyl, and 2-[2-(o-allylphenoxy)triethoxy]ethyl acrylates and methacrylates

\begin{tabular}{|c|c|c|c|}
\hline \multirow{2}{*}{ Monomer } & Time & Conversion & $\begin{array}{l}\text { Extent of } \\
\text { cyclization }\end{array}$ \\
\hline & $\mathrm{h}$ & $\%$ & $\%$ \\
\hline \multicolumn{4}{|l|}{ Acrylate } \\
\hline $\mathrm{A}(\mathrm{OE})_{2} \mathrm{~A}-14$ & 25 & 23 & 60 \\
\hline $\mathrm{A}(\mathrm{OE})_{3} \mathrm{~A}-17$ & 18.5 & 16 & 62 \\
\hline $\mathrm{A}(\mathrm{OE})_{4} \mathrm{~A}-20$ & 12.5 & 14 & 55 \\
\hline \multicolumn{4}{|l|}{ Methacrylate } \\
\hline $\mathrm{A}(\mathrm{OE})_{2} \mathrm{M}-14$ & 18 & 38 & 30 \\
\hline $\mathrm{A}(\mathrm{OE})_{3} \mathrm{M}-17$ & 8 & 33 & 25 \\
\hline $\mathrm{A}(\mathrm{OE})_{4} \mathrm{M}-20$ & 5.5 & 24 & 23 \\
\hline
\end{tabular}

a Solvent, toluene; [M], $0.5 \mathrm{moldm}^{-3}$; [AIBN], 0.01 mol dm ${ }^{-3}$; temp, $60^{\circ} \mathrm{C}$.

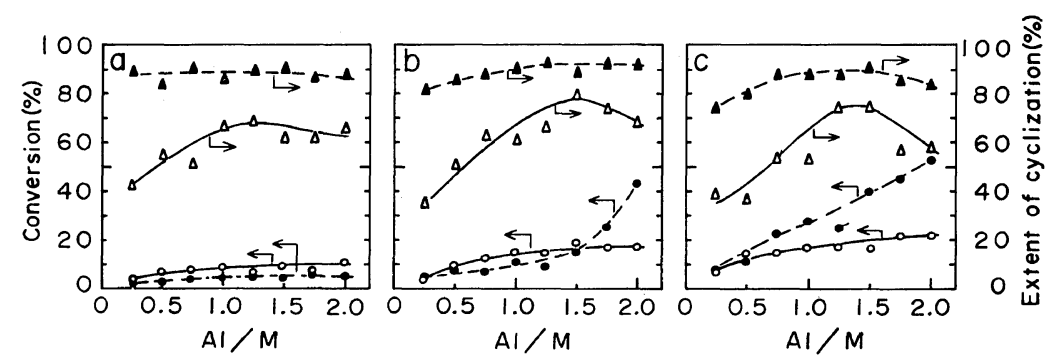

Figure 1. Effects of the $\mathrm{Al} / \mathrm{M}$ molar ratio on the polymerization of 2-[2-(o-allylphenoxy)ethoxy]ethyl acrylate and methacrylate in the presence of (a) $\mathrm{AlEt}{ }_{2} \mathrm{Cl}$, (b) $\mathrm{AlEt}_{1.5} \mathrm{Cl}_{1.5}$, and (c) $\mathrm{AlEtCl}_{2}$ : the conversion within $1 \mathrm{~h}$ for the acrylate $(O)$ and $4 \mathrm{~h}$ for the methacrylate $(O)$; the extent of cyclization for the acrylate $(\Delta)$ and the methacrylate $(\triangle) ;[\mathrm{M}], 0.5 \mathrm{~mol} \mathrm{dm}^{-3} ;$ AIBN/M molar ratio, 0.01 ; temp, $40^{\circ} \mathrm{C}$. 


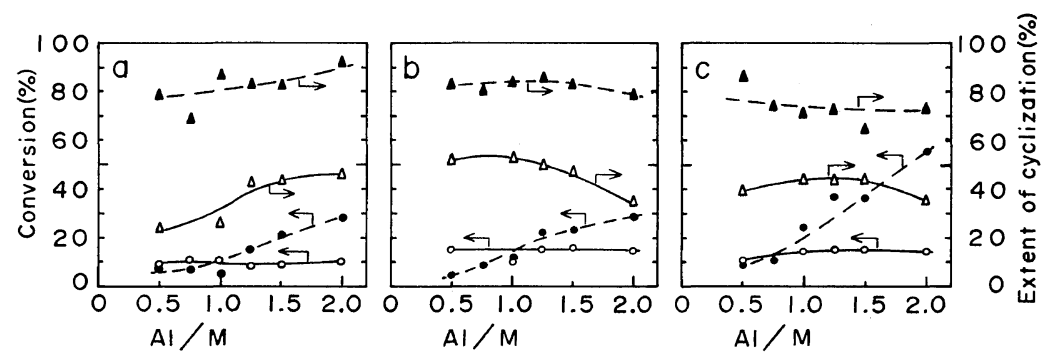

Figure 2. Effects of the $\mathrm{Al} / \mathrm{M}$ molar ratio on the polymerization of 2-[2-(o-allylphenoxy)diethoxy]ethyl acrylate and methacrylate in the presence of (a) $\mathrm{AlEt}{ }_{2} \mathrm{Cl}$, (b) $\mathrm{AlEt}_{1.5} \mathrm{Cl}_{1.5}$, and (c) $\mathrm{AlEtCl}_{2}$ : the conversion within $1 \mathrm{~h}$ for the acrylate $(\Theta)$ and $4 \mathrm{~h}$ for the methacrylate $(O)$; the extent of cyclization for the acrylate (A) and the methacrylate $(\triangle) ;[\mathrm{M}], 0.5 \mathrm{~mol} \mathrm{dm}^{-3}$; AIBN/M molar ratio, 0.01 ; temp, $40^{\circ} \mathrm{C}$.
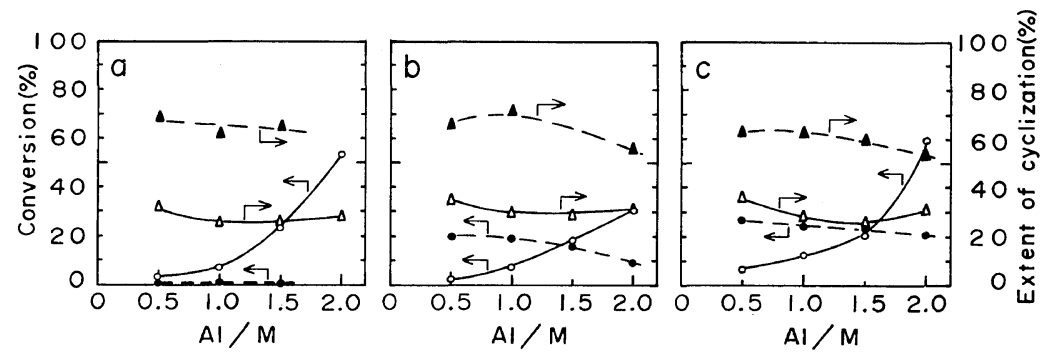

Figure 3. Effects of the $\mathrm{Al} / \mathrm{M}$ molar ratio on the polymerization of 2-[2-(o-allylphenoxyl)triethoxy]ethyl acrylate and methacrylate in the presence of (a) $\mathrm{AlEt}_{2} \mathrm{Cl}$, (b) $\mathrm{AlEt}_{1.5} \mathrm{Cl}_{1.5}$, and (c) $\mathrm{AlEtCl}_{2}$ : the conversion within $6 \mathrm{~h}$ for the acrylate $(\bigcirc)$ and the methacrylate $(\bigcirc)$; the extent of cyclization for the acrylate $(\boldsymbol{A})$ and the methacrylate $(\triangle) ;[\mathrm{M}], 0.5 \mathrm{~mol} \mathrm{dm}^{-3} ; \mathrm{AIBN} / \mathrm{M}$ molar ratio, 0.01 ; temp, $40^{\circ} \mathrm{C}$.

of alkylaluminum chlorides on the polymerization are shown in Figures 1, 2 and 3. The rate of the polymerization was indicated by a conversion within $1 \mathrm{hr}$ for $\mathrm{A}(\mathrm{OE})_{2} \mathrm{~A}$ and $\mathrm{A}(\mathrm{OE})_{3} \mathrm{~A}, 4 \mathrm{hr}$ for $\mathrm{A}(\mathrm{OE})_{2} \mathrm{M}$ and $\mathrm{A}(\mathrm{OE})_{3} \mathrm{M}$, and $6 \mathrm{hr}$ for $\mathrm{A}(\mathrm{OE})_{4} \mathrm{~A}$ and $\mathrm{A}(\mathrm{OE})_{4} \mathrm{M}$. Each alkylaluminum chloride was effective for increasing the extent of cyclization and the rate of the polymerization for all monomers. There was a subtle difference in the rates and cyclization extent among the alkylaluminum chlorides. The effects of alkylaluminum chlorides were reduced with increasing ring size. Plots of cyclization $v s$. ring size are shown in Figures 4 and 5 along with data from the oligomethylenes. The cyclization was maximum under the following conditions: a monomer concentration of $0.5 \mathrm{~mol} \mathrm{dm}^{-3}$ and temperature of $40^{\circ} \mathrm{C}$, at various $\mathrm{A} 1 / \mathrm{M}$ ratios. Polymerization with or without alkylaluminum chlorides caused greater cyclization for the oligooxyethylenes than the oligomethylenes, and also for the acrylates than the methacrylates also, there was considerable difference in the degree of cyclopolymerization. For the oligooxyethylene acrylates, cyclization without alkylaluminum chlorides exceeded $50 \%$ and was essentially independent of ring size. The effects of alkylaluminum chlorides were so prominent as to cause the cyclization to exceed $90 \%$ in 14 member ring and was $71 \%$ even in 20 member ring. For the oligooxyethylene methacrylates, the cyclization decreased sharply with increasing ring size, following from $90 \%$ in 11 member ring to $35 \%$ in 20 member ring even in the presence of alkylaluminum chlorides.

A quantitative comparison of cyclopolymerization was possible on the basis of the values for $k_{\mathrm{p}} / k_{\mathrm{c}}$, the ratio of the rate constants 


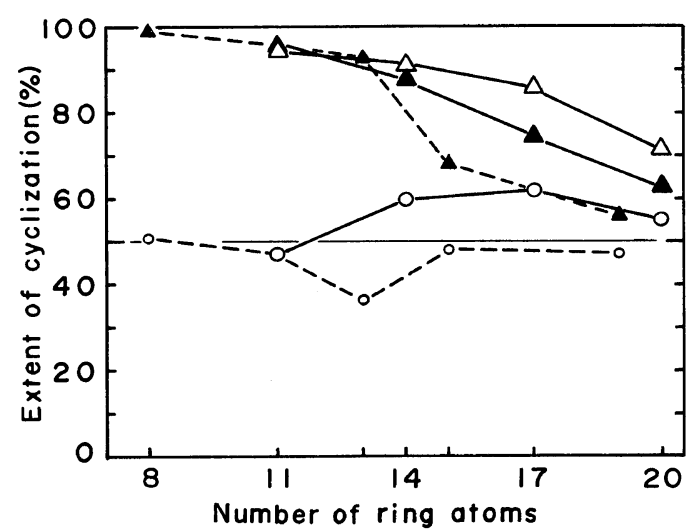

Figure 4. Extent of cyclization in the polymerizations of oligooxyethylene (-) and oligomethylene (---) acrylates: without alkylaluminum chlorides $(O)$; in the presence of $\mathrm{AlEt}_{1.5} \mathrm{Cl}_{1.5}(\triangle)$; in the presence of $\mathrm{AlEtCl}_{2}$ (A); $[\mathrm{M}], 0.5 \mathrm{~mol} \mathrm{dm}^{-3}$; temp, 60 and $40^{\circ} \mathrm{C}$ without and with alkylaluminum chlorides, respectively.

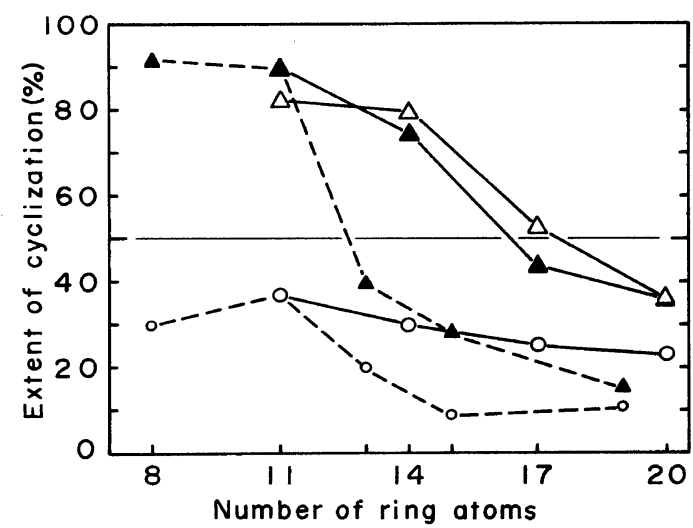

Figure 5. Extent of cyclization in the polymerizations of oligooxyethylene (- - ) and oligomethylene (--- ) methacrylates: without alkylaluminum chlorides $(O)$; in the presence of $\mathrm{AlEt}_{1.5} \mathrm{Cl}_{1.5}(\triangle)$; in the presence of $\mathrm{AlEtCl}_{2}(\Delta) ;[\mathrm{M}], 0.5 \mathrm{~mol} \mathrm{dm}^{-3}$; temp, 60 and $40^{\circ} \mathrm{C}$ without and with alkylaluminum chlorides, respectively.

Table II. The values of $k_{\mathrm{p}} / k_{\mathrm{c}}$ for the cyclopolymerization of oligooxyethylene and oligomethylene acrylates in the presence of $\mathrm{AlEtCl}_{2}{ }^{\mathrm{a}}$

\begin{tabular}{|c|c|c|c|c|c|}
\hline \multirow{2}{*}{ Monomers 3} & Temp & $k_{\mathrm{p}} / k_{\mathrm{c}}$ & \multirow{2}{*}{ Monomers 1} & \multirow{2}{*}{$\frac{\text { Temp }}{{ }^{\circ} \mathrm{C}}$} & \multirow{2}{*}{$\frac{k_{\mathrm{p}} / k_{\mathrm{c}}}{\mathrm{dm}^{3} \mathrm{~mol}^{-1}}$} \\
\hline & ${ }^{\circ} \mathrm{C}$ & $\mathrm{dm}^{3} \mathrm{~mol}^{-1}$ & & & \\
\hline & & & APA- $8^{6}$ & 40 & 0.045 \\
\hline $\mathrm{A}(\mathrm{OE}) \mathrm{A}-11^{2}$ & 20 & 0.17 & $\mathrm{~A}(\mathrm{OE}) \mathrm{A}-11$ & - & - \\
\hline $\mathrm{A}(\mathrm{OE})_{2} \mathrm{~A}-14$ & 40 & 0.20 & $\mathrm{~A}(\mathrm{OB}) \mathrm{A}-13^{3}$ & 20 & 0.27 \\
\hline $\mathrm{A}(\mathrm{OE})_{3} \mathrm{~A}-17$ & 40 & 0.55 & $\mathrm{~A}(\mathrm{OH}) \mathrm{A}-15^{3}$ & 40 & 0.99 \\
\hline $\mathrm{A}(\mathrm{OE})_{4} \mathrm{~A}-20$ & 40 & 0.98 & $\mathrm{~A}(\mathrm{OD}) \mathrm{A}-19$ & 40 & 10.3 \\
\hline
\end{tabular}

a $\mathrm{Al} / \mathrm{M}$ molar ratio, 1.0 .

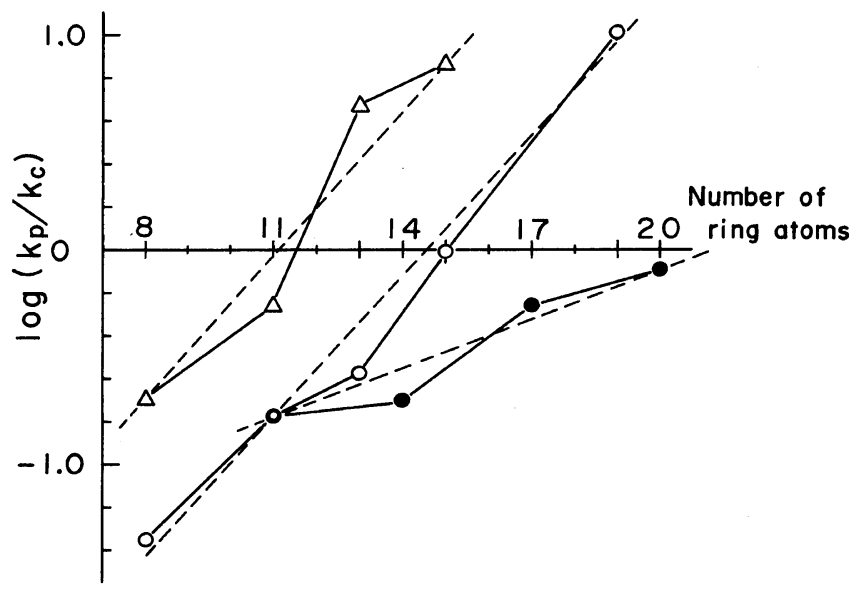

Figure 6. Variation in the values of $k_{\mathrm{p}} / k_{\mathrm{c}}$ according to ring size: for the oligooxyethylene acrylates ( $)$; for the oligomethylene acrylates $(\bigcirc)$; for the oligomethylene methacrylates $(\triangle)$. 
for linear propagation and cyclization, derived from $1 / f_{\mathrm{c}}=1+\left(k_{\mathrm{p}} / k_{\mathrm{c}}\right)$ [M]. The estimated values are summarized in Table II along with data previously reported for oligomethylene acrylates. ${ }^{3}$ As shown in Figure 6, plots of $\log \left(k_{\mathrm{p}} / k_{\mathrm{c}}\right) v s$. ring size give an approximately linear relation for the oligooxyethylene acrylates, as well as the oligomethylene acrylates and methacrylates. The slope corresponds to the difference in the free energy of activation against a one-membered increase in ring size ${ }^{3}$ $\left(\Delta\left(\Delta G_{\mathrm{c}}{ }^{\neq}-\Delta G_{\mathrm{p}}{ }^{\neq}\right)\right)$according to the equation, $\log \left(k_{\mathrm{p}} / k_{\mathrm{c}}\right)=\left(\Delta{G_{\mathrm{c}}}^{\neq}-\Delta{G_{\mathrm{p}}}^{\neq}\right) / R T$, and was found to be about $0.21 \mathrm{~kJ} \mathrm{~mol}^{-1}$ for oligooxyethylene acrylates against about 0.57 $\mathrm{kJ} \mathrm{mol}^{-1}$ for oligomethylene acrylates and methacrylates. Since a reduction in cyclopolymerization with increasing ring size describable in terms of the slope, it is clear that oligooxyethylenes are better than oligomethylenes for producing polymers with macrocyclic rings.

In $-\mathrm{CH}_{2}-\mathrm{O}-$ bonds, the potential barrier for rotation is considerably lower than in $\left(-\mathrm{CH}_{2}-\mathrm{CH}_{2}\right)$ bonds. The molecular chain, therefore, becomes kinetically more flexible by the introduction of oxygen atoms to the methylene chain. Because the flexibility of a molecule decreases the strain energy of transition state in intramolecular cyclization, transition should occur more easily for oligooxyethylenes than oligomethylenes. Our results support this expectation.

Acknowledgement. The authors gratefully acknowledge the support for this research through a grant from the Kurata Foundation.

\section{REFERENCES}

1. K. Yokota, N. Hirayama, and Y. Takada, Polym. J., 7, 629 (1975).

2. K. Yokota, T. Kakuchi, and Y. Takada, Polym. J., 8, 495 (1976).

3. K. Yokota, T. Kakuchi, A. Nanasawa, J. Iwata, and Y. Takada, Polym. J., 14, 509 (1982).

4. G. Illuminati, L. Mandolini, and B. Masci, J. Am. Chem. Soc., 99, 6308 (1977).

5. G. Illuminati, L. Mandolini, and B. Masci, J. Am. Chem. Soc., 103, 4142 (1981).

6. K. Yokota, T. Kakuchi, and Y. Takada, Polym. J., 10, 19 (1978). 